\title{
Varieties of Liberalization and the New Politics of Social Solidarity
}

\author{
2014. Cambridge University Press. Pages: 251 ISBN: 9781107679566
}

Are notions of solidarity obsolete in the face of the free market? Is there a single developed capitalism or are there many? Is there a best, most efficient way to delimit the state from the market and the public from the private or are there alternative, equally efficient solutions?

Comparative political economy is often based on the premise that the latter is true. In particular, the now classic Varieties of Capitalism (VofC) comparative approach postulates two types of institutional frameworks. The general idea was that each institutional solution generates positive externalities which may or may not be captured by specific solutions in other institutional domains. Therefore, the precondition for economic success of any given country is not any single institutional solution, but rather a consistent approach throughout the political economy cutting through finance, labor markets, education, inter-firm relations etc. The analysis of developed countries revealed two principal types of such institutional consistency - the coordinated market economy (CME) as a more restrictively regulated variety of capitalism and the liberal market economy (LME) as a more flexible variety oriented towards free markets.

The CME path to efficiency and growth is based on the formation of specific skills, protected and organized labor markets and long-term bank-centric corporate governance systems. This was considered as an approach of the Scandinavian countries, Germany, Austria, Switzerland, Belgium, the Netherlands and Japan. On the other hand, LME countries base their institutional comparative advantage on general skill formation, flexible labor markets with low unionization and short-term oriented corporate governance with predominant stock-market financing. These were said to be the USA, Canada, Ireland, the UK, Australia and New Zealand. 
This VofC comparative system has been challenged numerous times since its very beginnings. Its critics often claim that the CME countries face direct and indirect pressures towards liberalization (globalization, recession, Europeanization...) and that these inevitably transform the coordinated systems based on labor and employer unions. Kathleen Thelen, one of the leading scholars in the VofC field since its beginnings, with her 2014 book Varieties of Liberalization and the New Politics of Social Solidarity, joined this debate. Her book achieved two worthwhile accomplishments: firstly, the VofC approach is enriched with an attempt to attach developed trajectories of liberalizations to its logic, and secondly, the literature on institutional change takes a further step in explaining the intricate interplay between the agency incarnated in power resources/coalitions and structured path dependency.

The bulk of Thelen's book focuses on the comparison of the United States, Germany and Denmark across three comparative dimensions: Industrial relations, Vocational Education and Training (VET) and Labor market policy. All three institutions carry great importance for VofC analysis, even though a number of others could be added to this list. The choice of the surveyed institutions reflects numerous elements of Thelen's previous works in all three fields. To recount but a few, Thelen (2001) was a chapter in the original Hall and Soskice (2001) Varieties of Capitalism volume and dealt with varieties of labor policies, while Thelen (2004) was a volume dealing with the evolution of training systems. Also, the contribution to the better understanding of the problem of institutional change should be read in the rich context of her work with Wolfgang Streeck (Streeck and Thelen 2005), Peter Hall (Hall and Thelen 2009) and James Mahoney (Mahoney and Thelen 2009). In particular, Streeck and Thelen (2005) defined five modes of institutional change: displacement, layering, drift, conversion, and exhaustion. Several years later Thelen and Mahoney (2009) explored a more actor based approach building on these modes, but omitting exhaustion. Now, we are confronted with an analysis of only displacement, drift and conversion as relevant modes of institutional change through liberalization.

Specifically, displacement is a model of institutional change in which new institutions form and replace the old ones. In the context of liberalization trajectories, Thelen considers it a typical process conveying pure 
deregulation - a direct attack on the existing institutional arrangements, largely characteristic of US liberalization. The US always lacked strong coordinating capacities in industrial relations, but the trajectory of liberalization in recent decades saw a collapse of existing unions and collective bargaining and an erosion of real values of statutory minimum wages and benefits. Other institutional domains seem to carry traits of risk individualization and recent developments in education are focused on increasing the college enrollment, but without care for their successful completion. The education system therefore goes a long way in preserving the socio-economic status quo and similarly, the diminutive active labor measures are limited to a short term perspective and aimed at securing any form of jobs.

Drift occurs when the existing institutions remain stable, but exogenous events change their context and outcomes. It is applied here as a description of dualization processes typical for Germany - a tendency to continue with the protection of insiders, coupled with a disregard for new social risks on the periphery. While German industrial relations appear to remain typical of a CME invested in high skills, a strong social partnership in the manufacturing core of the economy with high unionization rates conceals low union coverage for the emergent service sector. Changes in the education system complement these developments. The high quality apprenticeship model is today challenged by the growth of the service sector (not based on specific skills required in manufacturing) and a drop in the available apprenticeship slots. Regardless of the continued need for institutional reform to remedy this, traditional institutions were generally defended, resulting in poor distributive effects with the winners and losers distinguished early in their careers. Germany also witnessed a substantial growth of the low-wage sector (after Haartz reforms 20022005) with substantial deregulation of agency work, fixed-term and mini jobs even as the well protected blue collar core was preserved.

Finally, conversion describes institutional changes which redirect institutions toward new functions. The produced conversion embedded flexibilization typical of Denmark, with institutions reoriented in order to collectivize risks in accordance with shifting social coalitions. While the German pattern of liberalization involved the perennial defense of traditional institutions, Denmark experienced the opposite. In industrial relations the formal 
institutions underwent a consistent decentralization but high levels of bargaining coverage/unionization were maintained across sectors and skill groups. The VET system now favors general skills more akin to the LME systems but the risk in education is nevertheless collectivized with the help of massive education subsidies and with unemployment training integrated in a comprehensive education/training system. While the dualization of labor presents a problem, generous social support, and training spending helped to preserve low rates of unemployment and a low share of low-wage jobs.

This analysis leads Thelen to conclude that the survival of egalitarian capitalism is entirely possible with the prerequisites of coordinated employers, coordinated labor and state support. These three points are far from obvious in social sciences today, even though they would have passed for common sense not long ago. Most importantly, the preservation of institutionalized solidarity depends on the ability of power alliances and institutional solutions to shift in order to accommodate new groups and exogenous events. Such an approach to liberalization is both desirable and plausible.

It is important to bear in mind what this book is not. It is not a primer on Varieties of Capitalism and students seeking an introduction should still reach for the original volume (Hall and Soskice 2001). It is also not a complete VofC study of the political economies of the analyzed countries. In the very least, a look into the corporate finance systems would be necessary to round the institutional picture. Therefore, it should primarily be read either by those already familiar with VofC or those interested in institutional change. They should find it a rewarding contribution to either field. While it does rush through the basics, and clearly limits the scope of analysis, Thelen's book more than compensates by completely rephrasing some of the most important questions social sciences face today. Thelen successfully applies the theory of institutional dynamics to an approach to comparative political economy which has up to now lent itself mostly to comparative statics.

In short, this is an important contribution to the institutional change literature and one of the most important Varieties of Capitalism related books since 2001. The work is timely, as it provides a useful reminder that 
uniform pressures do not necessitate uniform solutions. This lesson should be appreciated in particular on the periphery of the European Union, where perpetual reforms increasingly become an integral part of the political culture.

\section{Bibliography}

Hall, P. A. and Soskice, D., eds., 2001. Varieties of Capitalism: the Institutional Foundations of Comparative Advantage. Oxford University Press.

Hall, P. A. and Thelen, K., 2009. Institutional change in varieties of capitalism. Socio-Economic Review, 7(1), 7-34.

Mahoney, J. and Thelen, K., eds., 2009. Explaining Institutional Change: Ambiguity, Agency, and Power. Cambridge University Press.

Streeck, W. and Thelen, K. 2005. Beyond Continuity: Institutional Change in Advanced Political Economies. Oxford University Press.

Thelen, K., 2001. Varieties of Labor Politics in the Developed Democracies. In: Hall, P. A. and Soskice, D., eds., 2001. Varieties of capitalism: the institutional foundations of comparative advantage. Oxford University Press.

Thelen, K., 2004. How Institutions Evolve: The Political Economy of Skills in Germany, Britain, the United States, and Japan. Cambridge University Press.

Thelen, K., 2014. Varieties of Liberalization and the New Politics of Social Solidarity. Cambridge University Press. 